\title{
Trophic categories in a mammal assemblage: diversity in an agricultural landscape
}

\author{
Graziela Dotta $^{1,2}$ \& Luciano M. Verdade ${ }^{1}$
}

Biota Neotropica $v 7$ (n2)

http://www.biotaneotropica.org.br/v7n2/pt/abstract?short-communication+bn01207022007

Recebido em 08/05/06

Versão Reformulada recebida 26/02/07

Publicado em 01/05/07

\author{
${ }^{1}$ Laboratório de Ecologia Animal, Escola Superior de Agronomia “Luiz de Queiroz,", \\ Universidade de São Paulo - USP, \\ Avenida Pádua Dias, 11, CP 09, CEP 13418-900, Piracicaba, SP, Brazil \\ ${ }_{2}^{2}$ Autor para correspondência: Graziela Dotta, e-mail: grazidotta@ rocketmail.com, \\ http:// www.ciagri.usp.br/ lea/
}

\begin{abstract}
Dotta, G. \& Verdade, L.M. Trophic categories in a mammal assemblage: diversity in an agricultural landscape. Biota Neotrop. May/Aug 2007 vol. 7, no. 2 http://www.biotaneotropica.org.br/v7n2/pt/abstract?shortcommunication+bn01207022007. ISSN 1676-0603.

Mammals play an important role in the maintenance and regeneration of tropical forests since they have essential ecological functions and can be considered key-species in structuring biological communities. In landscapes with elevated anthropogenic pressure and high degree of fragmentation, species display distinct behavioral responses, generally related to dietary habits. The landscape of Passa-Cinco river basin, in the centraleastern region of São Paulo State, shows a high degree of anthropogenic disturbance, with sugar cane plantations, eucalyptus forests, native semideciduous forest remnants and pastures as the key habitat types in the region. We surveyed medium to large mammals in those habitats and determined species richness and relative abundance for each of the following trophic categories: Insectivore/Omnivores, Frugivore/Omnivores, Carnivores, Frugivore/ Herbivores and Herbivore/Grazers. Differences in species richness and relative abundance among habitats were tested using one-way analysis of variance, followed by Tukey test, considering 1) each of the trophic categories individually and 2) the set of categories together. Between July 2003 and June 2004, $284.4 \mathrm{~km}$ were walked and 22 species were recorded (20 native and two exotics). Analysis of variance did not detect differences in species richness for any of the trophic categories or for the assemblage. Considering relative abundance, the analysis detected significant differences only for the whole assemblage, with the assemblage being more abundant in sugar cane plantations compared to pastures. Our results indicate that the heterogeneous landscape of the study area is dominated by generalist species adapted to use different habitat types and food items.

Keywords: species richness, relative abundance, feeding guilds, agroecosystems.

\section{Resumo}

Dotta, G. \& Verdade, L.M. Categorias tróficas em uma assembléia de mamíferos: diversidade em paisagens agrícolas. Biota Neotrop. May/Aug 2007 vol. 7, no. 2 http://www.biotaneotropica.org.br/v7n2/pt/abstract?shortcommunication+bn01207022007. ISSN 1676-0603.

Os mamíferos têm um importante papel na manutenção e regeneração das florestas tropicais, pois apresentam funções ecológicas essenciais e podem ser considerados como espécies-chave na estruturação das comunidades biológicas. Em paisagens com forte pressão antrópica e alto grau de fragmentação, as espécies apresentam respostas distintas, geralmente relacionadas ao tipo de dieta. A bacia do Rio Passa-Cinco, região centro-leste do Estado de São Paulo, é uma paisagem fortemente antropizada, com predomínio de pastagens, seguido por canaviais, reflorestamento de eucalipto e fragmentos de floresta estacional semidecídua. Realizamos levantamentos nesses habitats, determinando a riqueza de espécies e abundância relativa nas seguintes categorias tróficas de mamíferos de médio e grande porte: Insetívoros/Onívoros, Frugívoros/Onívoros, Frugívoros/Herbívoros, Carnívoros e Herbívoros/Pastadores. Diferenças quanto à riqueza de espécies e abundância relativa entre os habitats foram testadas com análise de variância de um fator, seguida pelo teste de Tukey, considerando: 1) cada categoria trófica separadamente e 2) o conjunto de todas as categorias tróficas. Entre julho de 2003 e junho de 2004 percorremos $284,4 \mathrm{~km}$, registrando 20 espécies nativas e duas exóticas. Não foram detectadas diferenças na riqueza de espécies para nenhuma categoria trófica ou para a assembléia. Em relação à abundância relativa, a análise detectou diferenças para a assembléia como um todo, com as plantações de cana-de-açúcar apresentando maior abundância comparativamente as pastagens. Nossos resultados indicam que a paisagem heterogênea da área de estudo é dominada por espécies generalistas capazes de utilizar diversos tipos de habitats e itens alimentares disponíveis.
\end{abstract}

Palavras-chave: riqueza de espécies, abundância relativa, guildas tróficas, agroecossistemas. 


\section{Introduction}

Biological diversity can not be conserved only inside protected areas since most of the land surface is outside them. Nevertheless, there are still few studies focusing on the diversity in anthropogenic landscapes, especially in agroecosystems. Even so, it is common ground that species show distinct behavioral responses, generally related to dietary habits, to landscapes under strong anthropogenic pressure and with a high degree of fragmentation. The mammalian fauna plays an important role in the maintenance and regeneration of tropical forests, since they have essential ecological functions and can be considered key-species in structuring biological communities, through predation, seed dispersion, polinization, grazing and frugivory (Cuarón 2000).

Large predators, which demand large home range areas and have low population densities, tend to disappear, being generally replaced by smaller predators that have generalist habits (Laurance 1994). Generalist species can take advantage of the habitat mosaic of agricultural landscapes, since they are able to use different habitats and food items, as exemplified by mesopredators in fragmented landscapes (Gehring \& Swihart 2003). In addition, generalist species usually present increased predation rates due to the elevated prey diversity and density found on altered landscapes (Oehler \& Litvaitis 1996). Frugivores and large herbivores could also be affected by habitat alteration, since they need vast areas to find food resources and usually suffer high hunting pressures (Chiarello 1999).

Studies concerning medium to large-sized mammalian species, and particularly those focusing on their dietary requirements, were rarely conducted in agroecosystem landscapes. Gallina et al. (1996) studied the diversity of mammals in coffee plantations in Mexico and found $43 \%$ of loss in species diversity associated with a reduction in habitat complexity. Their results showed the importance of maintaining the arboreal strata inside coffee plantations, which provides food, shelter, nests, and protection for mammals. Another study conducted in an agricultural area concluded that tolerance to use croplands among carnivores was positively related to body size and niche breadth, with the larger species and those with generalized diets being more tolerant (Gehring \& Swihart 2003).

The main objective of this study was to describe and compare the richness and abundance of medium to large mammals among the main habitats in an agricultural landscape. We hypothesize that the richness of mammal assemblages will vary among different habitats occurring in an agroecosystem mosaic, because medium to largesized mammals with different diets vary in their tolerance to habitat alteration. Accordingly, we classified species in trophic categories and determine and compare the richness and relative abundance of the whole mammal assemblage and of the trophic categories among the main landscape habitats of a river basin in Central-eastern São Paulo State.

\section{Methods}

Passa-Cinco river basin $(52,757.60 \mathrm{ha})$ is located in the centraleastern region of the State of São Paulo $\left(22^{\circ} 14^{\prime}\right.$ to $22^{\circ} 30^{\prime} \mathrm{S}$ and $47^{\circ} 40^{\prime}$ to $47^{\circ} 55^{\prime} \mathrm{W}$, Itirapina and Ipeúna municipalities). The basin is an agricultural landscape composed by a mosaic of habitats, including pastures $(51.72 \%)$, sugar cane plantations (14.10\%), eucalyptus forests $(10.75 \%)$ and remnants of semideciduous native forest $(15.67 \%)$ as the main habitats types (Koffler 1993, Valente 2001). We established 16 sampling sites, four in each one of the habitats described above. In each site, we established the longest irregular transect possible limited by topography and the size of the habitat patches. Among sites, the length of transects varied from 2.8 to $4.0 \mathrm{~km}$ (mean of $3.6 \pm 0.35 \mathrm{~km}$ ) and the total walked length varied from 14 and $21 \mathrm{~km}$ (mean of $17.8 \pm$
$2.46 \mathrm{~km}$ ), totaling $71.1 \mathrm{~km}$ walked in pastures, $78.0 \mathrm{~km}$ in sugar cane plantations, $73.8 \mathrm{~km}$ in eucalyptus forests and $61.5 \mathrm{~km}$ in forest fragments. Transects were walked early in the morning (6:00 to 11:00 hours) seeking especially for indirect evidences (e.g. scats, tracks, scratches and sounds), because animal visualizations were very rare in previous visits to the area. Every two months, all the 16 sites were sampled, comprising a campaign. The sampling period was 12 months (from July/2003 to June/2004), including three campaigns in the dry season and two in the wet season, with $284.4 \mathrm{~km}$ walked during 82 days in the field.

The number of records for each species in each site was considered as its frequency of occurrence, and relative abundance was expressed as an index: frequency of occurrence $/ \mathrm{km}$ walked. Only the tracks were use for the statistical analysis, and in order to avoid overestimation, tracks were measured and followed along transects, especially in the case of cats and canids, so that each record represents a distinct group of tracks of different individuals. Species were grouped in trophic categories, adapted from Fonseca et al. (1996) as follows: Insectivore/Omnivores (IO), Frugivore/Omnivores (FO), Carnivores (CA), Frugivore/Herbivores (FH) and Herbivore/Grazers (HG). We reassembled Cabassous unicinctus from the Myrmecophage to the Insectivore-Omnivore category and Lontra longicaudis from the Piscivore to the Carnivore to avoid trophic categories with only one species. At last, Chrysocyon brachyurus was categorized as Frugivore/ Omnivore based on dietary studies (e.g. Motta Jr \& Martins 2002).

We used one-way analysis of variance, with post-hoc multiple comparisons using Tukey test, in order to check for possible differences in species richness and relative abundance among habitats, considering 1) each of the trophic categories individually and 2) the set of categories together. The homogeneity of variances was checked using Bartlett test. While homocedasticity was detected for all categories separately and also for the whole assemblage when considering species richness and relative abundance, it was not detected when considering the relative abundance of the Frugivore/Omnivores category. For this group, relative abundance data were ranked and the analysis of variance reflected differences between rank means. All tests were run in Statistica 6.0 (StatSoft Inc 2001).

\section{Results and Discussion}

We detected 20 native species of mammals and two exotics (Table 1). All the native species found were expected to occur in the study region (Patterson et al. 2005). Between the two exotic species - Lepus europaeus and Sus scrofa - the former seems to be well established in the region, demanding urgent studies concerning competition with the native Leporidae species Sylvilagus brasiliensis. Some species are expected to occur in the study area but were not recorded. Several of them are game species, as tapir (Tapirus terrestris), pampas deer (Ozotocerus bezoarticus), white-lipped peccary (Tayassu pecari), collared peccary (Pecari tajacu), jaguar (Panthera onca), and giant anteater (Mirmecophaga tridactyla). Other species not registered display primarily arboreal habits: a few small and large primate species (from the genera Callithrix and Alouatta), porcupines (from the genera Sphigurus and Coendou) and the collared anteater (Tamandua tetradactyla). Finally, the capybara (Hydrochoerus hydrochaeris) was not recorded since the study sites were distant from its required habitat (i.e. water body in association with food resources).

The one-way ANOVA did not detect significant differences in species richness ( $\mathrm{IO}: \mathrm{F}_{3.12}=0.95, \mathrm{p}=0.45 ; \mathrm{FO}: \mathrm{F}_{3.12}=1.48, \mathrm{p}=0.27$; CA: $\mathrm{F}_{3.12}=1.59, \mathrm{p}=0.24 ; \mathrm{FH}: \mathrm{F}_{3.12}=1.04, \mathrm{p}=0.41 ; \mathrm{HG}: \mathrm{F}_{3.12}=3.00$, $\mathrm{p}=0.07$ ) or relative abundance $\left(\mathrm{IO}: \mathrm{F}_{3.12}=2.15, \mathrm{p}=0.15\right.$; FO: $\mathrm{F}_{3.12}=2.18, \mathrm{p}=0.15 ; \mathrm{CA}: \mathrm{F}_{3.12}=0.75, \mathrm{p}=0.54 ; \mathrm{FH}: \mathrm{F}_{3.12}=1.06$, $\left.\mathrm{p}=0.40 ; \mathrm{HG}: \mathrm{F}_{3.12}=3.04, \mathrm{p}=0.07\right)$ for any of the trophic categories (Figures 1 and 2). Although species composition was not the same 
Table 1. Total, mean and standard deviation of the relative abundance and richness of medium and large mammals in each habitat type at the Passa-Cinco river basin, São Paulo, Brazil.

Tabela 1. Abundância relativa e riqueza de espécies de mamíferos de médio e grande porte em cada tipo de habitat da bacia do rio Passa-Cinco, São Paulo, Brasil (total, média e desvio padrão).

\begin{tabular}{|c|c|c|c|c|c|c|c|c|}
\hline \multirow[t]{3}{*}{ Trophic categories } & \multicolumn{8}{|c|}{ Habitat } \\
\hline & \multicolumn{2}{|c|}{ Pasture } & \multicolumn{2}{|c|}{ Sugar cane plantations } & \multicolumn{2}{|c|}{ Eucalyptus forest } & \multicolumn{2}{|c|}{ Forest fragments } \\
\hline & Total & Mean & Total & Mean & Total & Mean & Total & Mean \\
\hline \multicolumn{9}{|c|}{ INSECTIVORE/OMNIVORE } \\
\hline \multicolumn{9}{|l|}{ Xenarthra } \\
\hline \multicolumn{9}{|l|}{ Dasypodidae } \\
\hline Cabassous unicinctus & - & - & - & - & 0.25 & $0.06 \pm 0.06$ & 0.07 & $0.02 \pm 0.04$ \\
\hline Dasypus novemcinctus & 0.32 & $0.08 \pm 0.05$ & 0.27 & $0.07 \pm 0.10$ & 0.52 & $0.13 \pm 0.07$ & 0.65 & $0.16 \pm 0.17$ \\
\hline Euphractus sexcinctus & 0.33 & $0.08 \pm 0.03$ & 1.00 & $0.25 \pm 0.34$ & 0.65 & $0.16 \pm 0.33$ & 0.20 & $0.05 \pm 0.10$ \\
\hline \multicolumn{9}{|l|}{ Carnivora } \\
\hline \multicolumn{9}{|l|}{ Canidae } \\
\hline Cerdocyon thous & 1.29 & $0.32 \pm 0.12$ & 4.06 & $1.02 \pm 0.09$ & 1.09 & $0.27 \pm 0.13$ & 1.86 & $0.47 \pm 0.43$ \\
\hline \multicolumn{9}{|l|}{ Mustelidae } \\
\hline Conepatus chinga & - & - & 0.10 & $0.03 \pm 0.05$ & 0.22 & $0.06 \pm 0.11$ & - & - \\
\hline Total number of species & 3 & $3.00 \pm 0.00$ & 4 & $2.50 \pm 0.58$ & 5 & $3.25 \pm 1.26$ & 4 & $2.25 \pm 1.26$ \\
\hline Total abundance & 1.94 & $0.49 \pm 0.18$ & 5.43 & $1.37 \pm 0.26$ & 2.73 & $0.68 \pm 0.67$ & 2.78 & $0.70 \pm 0.73$ \\
\hline \multicolumn{9}{|l|}{ FRUGIVORE/OMNIVORE } \\
\hline \multicolumn{9}{|l|}{ Primates } \\
\hline \multicolumn{9}{|l|}{ Cebidae } \\
\hline Cebus apella & - & - & - & - & - & - & 0.68 & $0.17 \pm 0.25$ \\
\hline Callicebus personatus & - & - & - & - & - & - & 0.29 & $0.07 \pm 0.15$ \\
\hline \multicolumn{9}{|l|}{ Carnivora } \\
\hline \multicolumn{9}{|l|}{ Canidae } \\
\hline Chrysocyon brachyurus & 0.05 & $0.01 \pm 0.03$ & 0.11 & $0.03 \pm 0.03$ & 2.51 & $0.12 \pm 0.08$ & - & - \\
\hline \multicolumn{9}{|l|}{ Procyonidae } \\
\hline Nasua nasua & - & - & 0.11 & $0.03 \pm 0.03$ & 0.05 & $0.01 \pm 0.03$ & 0.47 & $0.12 \pm 0.17$ \\
\hline Procyon cancrivorous & 0.05 & $0.01 \pm 0.03$ & 0.55 & $0.14 \pm 0.15$ & 0.05 & $0.01 \pm 0.03$ & 0.05 & $0.01 \pm 0.03$ \\
\hline Total number of species & 2 & $0.50 \pm 1.00$ & 3 & $1.75 \pm 0.50$ & 3 & $1.50 \pm 0.58$ & 4 & $1.75 \pm 1.50$ \\
\hline Total abundance & 0.10 & $0.03 \pm 0.05$ & 0.77 & $0.20 \pm 0.14$ & 0.58 & $0.15 \pm 0.08$ & 1.49 & $0.37 \pm 0.39$ \\
\hline CARNIVORE & & & & & & & & \\
\hline Carnivora & & & & & & & & \\
\hline Felidae & & & & & & & & \\
\hline Leopardus pardalis & - & - & 0.06 & $0.02 \pm 0.03$ & 0.05 & $0.01 \pm 0.03$ & 0.18 & $0.05 \pm 0.06$ \\
\hline Small cats $*$ & - & - & 0.42 & $0.11 \pm 0.10$ & 0.17 & $0.04 \pm 0.03$ & 0.18 & $0.05 \pm 0.05$ \\
\hline Puma concolor & 0.10 & $0.03 \pm 0.03$ & - & - & 0.22 & $0.01 \pm 0.03$ & 0.25 & $0.06 \pm 0.05$ \\
\hline Mustelidae & & & & & & & & \\
\hline Eira barbara & - & - & - & - & 0.42 & $0.03 \pm 0.04$ & 0.07 & $0.02 \pm 0.04$ \\
\hline Galictis cuja & - & - & 0.05 & $0.01 \pm 0.03$ & 0.20 & $0.05 \pm 0.06$ & - & - \\
\hline Lontra longicaudis & 0.16 & $0.04 \pm 0.08$ & - & - & - & - & 0.05 & $0.01 \pm 0.03$ \\
\hline Total number of species & 2 & $0.75 \pm 0.96$ & 3 & $1.25 \pm 0.96$ & 5 & $2.25 \pm 0.96$ & 5 & $2.25 \pm 1.71$ \\
\hline Total abundance & 0.26 & $0.07 \pm 0.10$ & 0.53 & $0.14 \pm 0.13$ & 0.59 & $0.15 \pm 0.07$ & 0.73 & $0.19 \pm 0.14$ \\
\hline FRUGIVORE/HERBIVOR & & & & & & & & \\
\hline Rodentia & & & & & & & & \\
\hline Cuniculidae & & & & & & & & \\
\hline Cuniculus paca & 0.05 & $0.01 \pm 0.03$ & 0.31 & $0.08 \pm 0.12$ & - & - & 0.07 & $0.02 \pm 0.04$ \\
\hline Dasyproctidae & & & & & & & & \\
\hline Dasyprocta azarae & - & - & 0.06 & $0.02 \pm 0.03$ & - & - & 0.07 & $0.02 \pm 0.04$ \\
\hline Artiodactyla & & & & & & & & \\
\hline Cervidae & & & & & & & & \\
\hline Mazama sp. & 0.27 & $0.07 \pm 0.10$ & 0.78 & $0.20 \pm 0.14$ & 0.10 & $0.30 \pm 0.23$ & 1.29 & $0.32 \pm 0.27$ \\
\hline Suidae & & & & & & & & \\
\hline Sus scrofa & - & - & 0.94 & $0.24 \pm 0.47$ & 0.05 & $0.01 \pm 0.03$ & 0.38 & $0.10 \pm 0.19$ \\
\hline Total number of species & 2 & $0.75 \pm 0.96$ & 4 & $2.00 \pm 1.41$ & 2 & $1.25 \pm 0.50$ & 4 & $1.50 \pm 1.00$ \\
\hline Total abundance & 0.32 & $0.08 \pm 0.13$ & 2.09 & $0.54 \pm 0.62$ & 1.26 & $0.32 \pm 0.22$ & 1.81 & $0.46 \pm 0.36$ \\
\hline
\end{tabular}


Table 1. Continued...

\begin{tabular}{|c|c|c|c|c|c|c|c|c|}
\hline \multirow[t]{3}{*}{ Trophic categories } & \multicolumn{8}{|c|}{ Habitat } \\
\hline & \multicolumn{2}{|c|}{ Pasture } & \multicolumn{2}{|c|}{ Sugar cane plantations } & \multicolumn{2}{|c|}{ Eucalyptus forest } & \multicolumn{2}{|c|}{ Forest fragments } \\
\hline & Total & Mean & Total & Mean & Total & Mean & Total & Mean \\
\hline \multicolumn{9}{|l|}{ HERBIVORE/GRAZER } \\
\hline \multicolumn{9}{|l|}{ Lagomorpha } \\
\hline \multicolumn{9}{|l|}{ Leporidae } \\
\hline Lepus europaeus & 0.05 & $0.01 \pm 0.03$ & 0.56 & $0.14 \pm 0.11$ & 0.35 & $0.09 \pm 0.08$ & 0.07 & $0.02 \pm 0.04$ \\
\hline Total number of species & 1 & $0.25 \pm 0.50$ & 1 & $1.00 \pm 0.00$ & 1 & $0.75 \pm 0.50$ & 1 & $0.25 \pm 0.50$ \\
\hline Total abundance & 0.05 & $0.01 \pm 0.03$ & 0.56 & $0.14 \pm 0.11$ & 0.35 & $0.09 \pm 0.08$ & 0.07 & $0.02 \pm 0.04$ \\
\hline \multicolumn{9}{|l|}{ ASSSEMBLAGE } \\
\hline Total number of species & 10 & $5.25 \pm 2.63$ & 15 & $8.50 \pm 2.08$ & 16 & $9.00 \pm 2.16$ & 18 & $8.00 \pm 3.16$ \\
\hline Total abundance & 2.67 & $0.67 \pm 0.41$ & 9.38 & $2.35 \pm 0.65$ & 5.51 & $1.38 \pm 0.95$ & 6.88 & $1.72 \pm 0.79$ \\
\hline
\end{tabular}
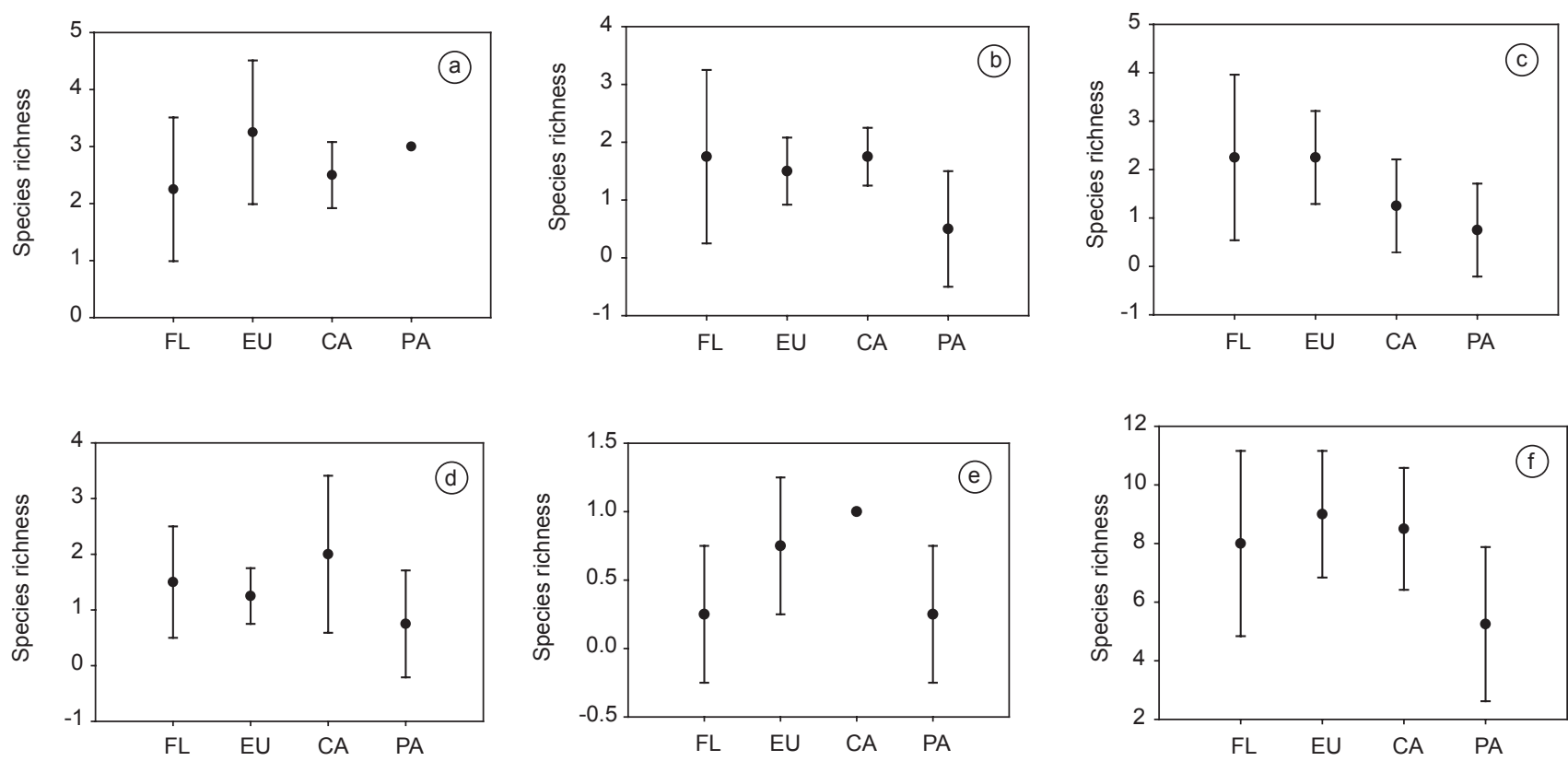

Figure 1. Mean and standard deviation of mammal richness for each habitat type (FL - Forest fragments, EU - Eucalyptus forests, CA - Sugar cane plantations, PA - Pastures) sampled in Passa-Cinco river basin, São Paulo, Brazil. a) Insectivore/Omnivores; b) Frugivore/Omnivores; c) Carnivores; d) Frugivore/ Herbivores; e) Herbivore/Grazers, and f) Assemblage.

Figura 1. Média e desvio padrão para riqueza de mamíferos em cada habitat da bacia do rio Passa-Cinco, São Paulo, Brasil (FL- fragmentos florestais, EU - eucalipto, CA - cana-de-açúcar, PA - pastagens). a) Insetívoros/Onívoros; b) Frugívoros/Onívoros; c) Carnívoros; d) Frugívoros/Herbívoros; e) Herbívoros/ Pastadores; e f) Assembléia.

among habitats, with several species occurring in just one or a few habitat types (Table 1), the similarity concerning both the number of species and relative abundance of each category indicates a uniform trophic structure in mammal assemblages among habitats. Although unexpected, these results can be understood in the light of the fact that the species recorded in the study area are among the most generalist for each of the trophic categories. Those species may benefit from habitat fragmentation due to their capacity to use different sorts of habitat and food items (Yahner 1988).

For example, the most abundant species recorded in the region is an Insectivore/Omnivore, the Crab-eating fox (Cerdocyon thous), a widespread species in Brazil, occurring in different biomes and vegetation types, and presenting generalist feeding habits (Courtenay \& Maffei 2004). Furthermore, Herbivore/Grazers were represented only by an exotic species, the European hare (Lepus europaeus), which is a generalist Leporidae, apparently benefiting from agriculture expansion (Aurichio \& Olmos 1999). In fact, this species was more common in sugar cane plantations (Table 1). The footprints of the European hare and the native Leporidae, Sylvilagus brasiliensis (tapiti), which was recorded in the study area only by feces, can be identified by differences in size. Carnivore category, on the other hand, included both species with generalist habits (e.g. Puma - Puma concolor, Grison - Galictis cuja) as well as species with more specific habitat requirements (e.g. small felids - Leopardus spp., Ocelot - Leopardus pardalis, Otter - Lontra longicaudis) (Sunquist \& Sunquist 2002, Parera 2002).

Considering the set of categories analyzed together, one-way ANOVA did not detect significant differences in species richness $\left(\mathrm{F}_{3.12}=1.73, \mathrm{p}=0.21\right)$, but a difference was detected in relative abundance $\left(\mathrm{F}_{3.12}=3.69, \mathrm{p}=0,04\right)$ (Figures 1 and 2$)$. The post hoc 

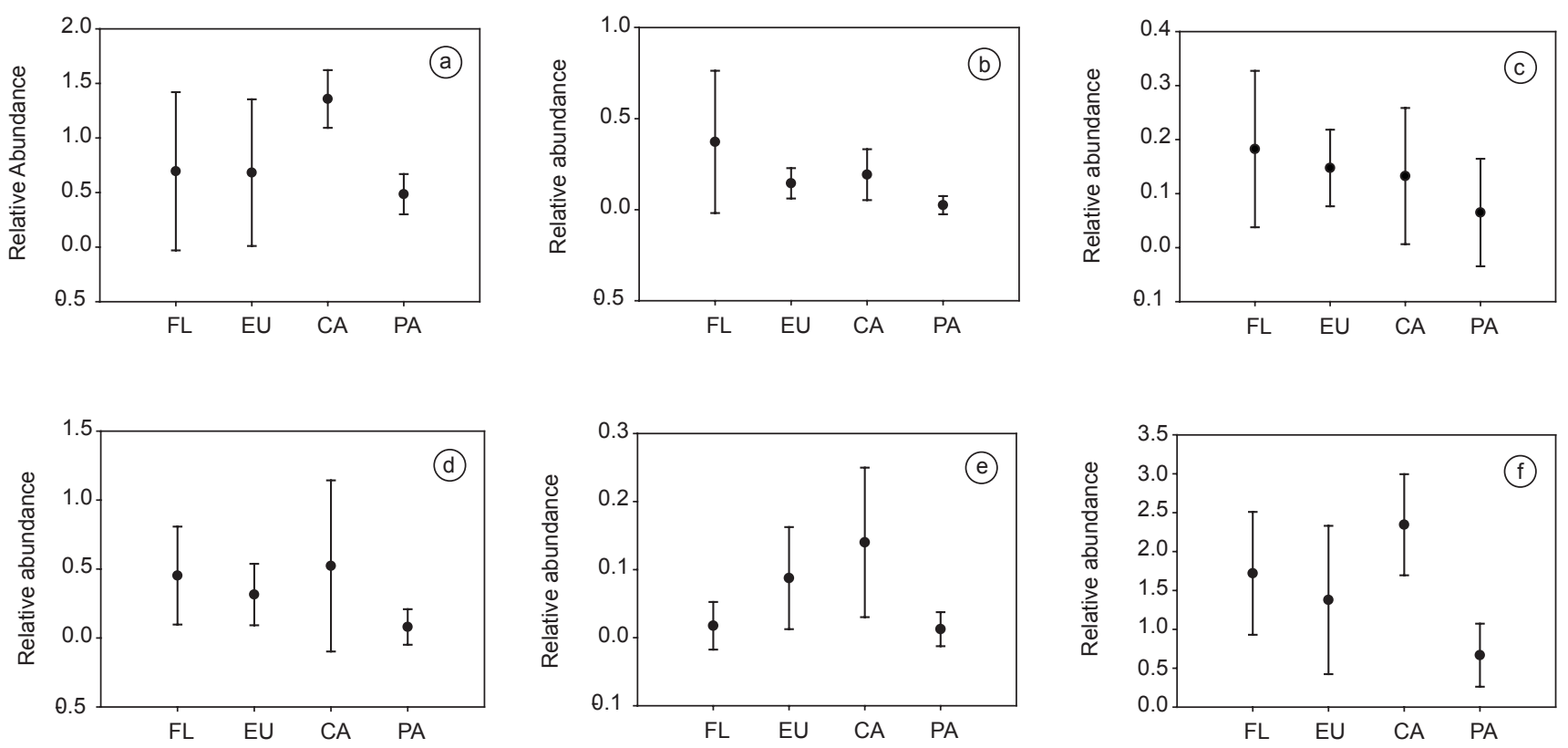

Figure 2. Mean and standard deviation of mammal relative abundance for each habitat type (FL - Forest fragments, EU - Eucalyptus forests, CA - Sugar cane plantations, PA - Pastures) sampled in Passa-Cinco river basin, São Paulo, Brazil. a) Insectivore/Omnivores, b) Frugivore/Omnivores, c) Carnivores, d) Frugivore/Herbivores, e) Herbivore/Grazers, and f) Assemblage.

Figura 2. Média e desvio padrão para abundância relativa de mamíferos em cada habitat da bacia do rio Passa-Cinco, São Paulo, Brasil (FL - fragmentos florestais, EU - eucalipto, CA - cana-de-açúcar, PA - pastagens). a) Insetívoros/Onívoros, b) Frugívoros/Onívoros, c) Carnívoros, d) Frugívoros/Herbívoros, e) Herbívoros/Pastadores, e f) Assembléia.

test indicated that sugar cane plantations harbor a significantly higher abundance compared to pastures $(p=0.03)$. This result could be related to the availability of prey items, since small mammal abundance in the Passa-Cinco region is also higher in sugar cane than in pastures (Gheler-Costa 2006). Moreover, the presence of cattle itself could be chasing away some species from the pastures. Stephens et al. (2001), monitoring livestock effect upon mammals, found several negative effects, as direct competition for food resources, attacks of domestic dogs, and disease dissemination.

The results we presented indicate that heterogeneous landscape such as the Passa-Cinco basin may still be capable to support a considerable diversity of mammal trophic categories, although most of the species in each of these categories display generalized habits. The relationship between mammal diversity and vegetation structure complexity has been reported in natural systems: a higher complexity and heterogeneity in vegetation structure supports a higher diversity and abundance of mammals (August 1983, Robinson \& Redford 1986, Smythe 1986). Thus, in order to promote the maintenance and increase the diversity and abundance of mammals in Passa-Cinco region, available sources of food and protection should be guaranteed. From a conservation perspective, it is important to assure the maintenance of the semideciduous forest remnants, as well as to restore the gallery forest, inexistent in almost all the streams, to warrant the presence of more specialized species, including primates and most of the frugivores.

\section{Acknowledgments}

This research was funded by FAPESP (Process number: 01/13251-4). CAPES supplied a scholarship to G. Dotta. We would like to thank Diego Queirolo for criticism and suggestions to earlier drafts of the manuscript. We are also grateful to an anonymous reviewer for providing helpful comments and to Renata Pardini for the detailed revisions during the editorial process.

\section{References}

AUGUST, P. 1983. The role of habitat complexity and heterogeneity in structuring tropical mammal communities. Ecol. 64(6):1495-1507.

AURICHIO, P. \& OLMOS, F. 1999. Nortward range extensions for the European hare, Lepus europaeus (Pallas, 1778 Lagomorpha - Leporidae), in Brazil. Pub. Avul. IPBHN 2:1-5.

CHIARELLO, A.G. 1999. Effects of fragmentation of the Atlantic forest on mammals communities in the south-eastern Brazil. Biol. Conserv. 89:71-82.

COURTENAY, O. \& MAFFEI, L. 2004. Crab-eatin fox (Cerdocyon thous). In Status Survey and Conservation Action Plan of Canids: Foxes, Wolves, Jackals and Dogs. (C. Sillero-Zubiri, M. Hoffmann \& D.W. Macdonald, eds.). IUCN/SSC Canid Specialist Group, Gland, Switzerland and Cambridge, p.32-38.

CUARÓN, A.D. 2000. A global perspective on habitat disturbance and tropical rainforest mammals. Conserv. Biol. 14(6):1574-1579.

FONSECA, G.B.A., HERRMANN, G., LEITE, Y.L.R., MITTERMEIER, R.A., RYLANDS, A.B. \& PATTON, J.L. 1996. Lista anotada dos mamíferos do Brasil. Occas. Pap. Conserv. Biol. n4, 38p.

GALLINA, S., MANDUJANO, S. \& GONZALEZ-ROMERO, A. 1996. Conservation of mammalian biodiversity in coffee plantations of Central Veracruz, México. Agrof. Syst. 33:13-27.

GEHRING, T.M. \& SWIHART, R.K. 2003. Body size, niche breadth, and ecologically scaled responses to habitat fragmentation: mammalian predators in an agricultural landscape. Biol. Conserv. 109:283-295.

GHELER-COSTA, C. 2006. Distribuição e abundância de pequenos mamíferos em relação à paisagem da bacia do rio Passa-Cinco, São Paulo, Brasil. 
Tese de Doutorado, Escola Superior de Agricultura Luiz de Querioz, Universidade de São Paulo, Piracicaba.

KOFFLER, N.F. 1993. Uso das terras da bacia do rio Corumbataí em 1990. Geografia 18(1):135-150.

LAURANCE, W.F. 1994. Rainforest fragmentation and the structure of small mammal communities in tropical Queensland. Biol. Conserv. 69:23-32.

MOTTA JR, J.C. \& MARTINS, K. 2002. The frugivorous diet of the maned wolf, Chrysocyon brachyurus, in Brazil: ecology and conservation. In Seed Dispersal and Frugivory: Ecology, Evolution and conservation. (D.J. Levey, W.R. Silva \& M. Galetti, eds.). CABI Publishing, Wallingford, p.291-304.

OEHLER, J.D \& LITVAITIS, J.A. 1996. The role of spatial scale in understanding responses of medium-sized carnivores to forest fragmentation. Can. J. Zool. 74:2070-2079.

PARERA, A. 2002. Los mamíferos de la Argentina y la región Austral de Sudamérica. El Ateneo, Buenos Aires.

PATTERSON, B.D., CEBALlOS, G., SECHREST, W., TOGNELLI, M.F., BROOKS, T., LUNA, L., ORTEGA, P., SALAZAR, I. \& YOUNG, B.E.
2005. Digital Distribution Maps of the Mammals of the Western Hemisphere, version 2.0. NatureServe, Arlington.

ROBINSON, J.G. \& REDFORD, K.H. 1986. Body size, diet, and population density of Neotropical forest mammals. Am. Nat. 128(5):665-680.

SMYTHE, N. 1986. Competition and resource partitioning in the guild of Neotropical terrestrial frugivorous mammals. Ann. Rev. Ecol. Syst. 17:169-188.

STATSOFT INC. 2001. Statistica - data analysis software system, version 6.

SUNQUIST, M. \& SUNQUIST, F. 2002. Wild cats of the world. The University of Chicago Press, Chicago.

VALENTE, R.O.A. 2001. Análise da estrutura da paisagem na bacia do rio Corumbataí. Dissertação de Mestrado, Escola Superior de Agricultura "Luiz de Queiroz", Universidade de São Paulo.

YAHNER, R.H. 1988. Changes in wildlife communities near edges. Conserv. Biol. 2:333-339. 